\title{
The Beak of the Finch: Insights into the Economic Development of Small Economies
}

\author{
GODFREY BALDACCHINO* AND GEOFFREY BERTRAM** \\ *University of Prince Edward Island, Canada \\ **Victoria University of Wellington, New Zealand
}

\begin{abstract}
Many scholarly analyses of small economies over the past two decades have been premised on the implicit understanding that a state's small population size, compounded by such factors as islandness and remoteness from markets, is to blame for an inherent and unavoidable economic vulnerability. The article critiques the core features of this approach, and proposes in turn to discuss and profile the development trajectories of small economies from the vantage point of the strategic flexibility used by small states (at multiple levels as individuals, household units, corporate entities and complete jurisdictions) in seeking to exploit opportunities and maximize economic gains in a turbulent and dynamic external environment with which they must engage. Keeping alive a portfolio of skills and revenue streams enables these actors to migrate intersectorally as well as trans-nationally.
\end{abstract}

KEY WORDS: capacity, finches, islands, SIDS, small economies, small states, strategic flexibility, vulnerability

\section{Introduction: Vulnerability or Strategic Flexibility?}

It is common to see small states, ${ }^{1}$ and in particular small island states, described as 'vulnerable', from which a case is often mounted for granting especially favourable concessions to small island developing states (SIDS). In this paper, we argue that this conceptual approach to the analysis of small states, however useful it may be in terms of diplomatic leverage, is not the right place to start if one is seeking an analytical understanding of how small states survive, develop, and exploit the opportunities and threats that face them in the global order.

The vulnerability paradigm which we critique is a version of structural determinism which asserts that from small size flows weakness, and from weakness flows inability to manage effectively the challenges one faces, and from this

\footnotetext{
Correspondence Address: Godfrey Baldacchino, Canada Research Chair (Island Studies), University of Prince Edward Island, C1A 4P3 Canada. Email: gbaldacchino@upei.ca; Geoffrey Bertram, School of Economics and Finance, Victoria University of Wellington, PO Box 600, Wellington, New Zealand. Email: Geoff.Bertram@vuw.ac.nz
} 
incapacity follows some sense of entitlement as well as of an obligation upon the international community to provide unusually generous development and diplomatic assistance in response to the 'special needs' of small states (Briguglio, 1995; Charles et al., 1997; Commonwealth Secretariat, no date; Commonwealth Consultative Group 1985; Crowards and Coulter 1998, 1999; Streeten, 1993; United Nations Committee on Development Policy, 2005).

The strategic flexibility paradigm, set out here as an alternative approach, is grounded in empirical observation: many small states not only survive but thrive in the modern global order. Briguglio's (1995) 'vulnerability index' correlates positively, not negatively, with GDP per capita (Armstrong et al., 1998). The survival into the modern era of a large number of successful small states and subnational jurisdictions is evidence, we suggest, not of weakness but of underlying elements of strength that are inherent in small, often island, societies.

Many of the statistical measures paraded before international agencies as signs of vulnerability and special needs are in fact the outcomes of purposive and rational strategic behaviour by active agents (both individuals and collectivities) operating in microstate environments. Successful small countries actively increase their trade ratios, narrow their economic diversification, increase their reliance on financial transfers from larger metropolitan powers, explore alternatives to industrialization, and embark on high-volatility activities while making due provision to retain windfall gains to offset losses.

Statistical indices made up of weighted averages of these indicators do not serve as proof of vulnerability; rather, they presume it (e.g. Charles et al., 1997, p. 13). Circularity is pervasive. The 'economic vulnerability index' used by the United Nations Committee on Development Policy (2005) to evaluate whether small states should be graduated from least-developed status is constructed from seven indicators, one of which is population size: to be small is to be vulnerable. The Commonwealth Secretariat's "Composite Vulnerability Index" contains three indicators chosen from a candidate list of 29 on the entirely ad hoc basis that they give the best statistical prediction of output volatility, which was presumed to equate to 'vulnerability', notwithstanding that the result was to rank Singapore among the ten 'most vulnerable' countries in the Commonwealth (Atkins et al., 2000).

To avoid misunderstanding, we are not saying that small states are not challenged by their size and location. Every country is, to some extent. Our point is that strategically intelligent evolutionary responses to the particular challenges of smallness, islandness, remoteness, higher propensity to hurricanes, and so on, have as their outcomes the statistically measured indicators used in 'vulnerability index' exercises. Hyper-specialization, openness, reliance upon external sources of finance, living with cycles of volatility, all go with the territory and do not in themselves carry any necessary connotation of weakness, fragility, or vulnerability. They are evidence of "the ability of the receiving agents to respond to risk" (Charles et al., 1997, p. 14). Having produced a vulnerability index, Briguglio (1995, p. 1624) recommended that appropriate policies for SIDS should comprise "niche-filling export strategy" and "flexible specialization"; both of these, if pursued successfully, would cause 'vulnerability' (as measured by the index) to rise, rather than to fall. 


\section{Of Finches, Frogs and Small States}

In The Beak of the Finch, Jonathan Weiner writes about the important contributions to evolutionary science that have been made possible, and continue to be made, from meticulous and sustained observations of the changing size and shape of the beaks of finches that live on the island of Daphne Major, in the Galápagos archipelago. This island is small enough to have allowed intrepid researchers, led by Peter and Rosemary Grant, to keep close track of the inter-generational patterns and trends of all the finches on this island for various decades - an almost perfect controlled experiment. When correlated with such environmental variables as frequency and quantity of rain, drought, and seed supply, the picture which emerges is one that shows evolution in action, and one where the beak of the finch is the protagonist, given its crucial role in the survival of the birds. Hybridization is common. The mean size and shape of the beak of finches on Daphne Major changes inter-generationally, in response to climatic conditions, even if by a few millimetres, which can and does spell the difference between life and death (Weiner, 1994).

Writing a decade earlier, Peter Katzenstein (1985) reported on the success of the small European states in his book Small States in World Markets. The relatively small size of such European states as Austria, Sweden and Switzerland-although much larger than any of the world's microstates - makes it impossible even for them to set prices or to determine international trade regimens; they are thus obliged to nimbly ride the waves that would otherwise destroy them. They are characterized by rapid policy deployments, and a resolve in confronting the outside world that cuts across political party lines - features that larger jurisdictions would be hard put to copy. $^{2}$ Katzenstein argues that the small European state has been forced to develop patterns of active, flexible, societally orchestrated adjustment as a result of international market exposure and the strategic disadvantages of small size in negotiating international terms of trade. Small European countries are typically politically integrated and highly developed welfare states where social embeddedness of the economy is promoted through negotiation, rather than polarization. This embedding takes the form of active state intervention, ranging from a large public sector and incomes policies to generous welfare expenditure. A spirit of political cooperation and a shared vision of international economic relations allow efficient adaptation to both unforeseen exogenous developments and the threats of an inherently turbulent and unpredictable international environment (Katzenstein, 1985; also Midttun, Gautesen and Gjolberg, 2006).

Katzenstein concludes his 1985 work, as well as his 2003 rejoinder, with an "Aesopian fable", after the famous storyteller from Classical Greece, which is worth reproducing in full:

The adjustment strategy of the small European states is summed up by the story of the snake, the frog and the owl. Fearful of being devoured by the snake, the frog asks the owl how he [sic] might survive. The owl's response is brief and cryptic. Learn how to fly. None of the small European states have to soar like the eagle. What they have learned to cultivate is an amazing capacity to jump. Although they appear to land on their stomachs, in fact they always land on their feet and retain the ability to jump again and again in different directions, 
correcting their course as they go along. In a world of great uncertainty and high-risk choices, this is an intelligent response. Frogs can escape snakes, and the small corporatist states can continue to prosper: not because they have found a solution to the problem of change but because they have found a way to live with change. (Katzenstein, 1985, p. 211; 2003, p. 30)

\section{Flexible Adjustment Rules}

What finches, frogs and small states have in common is flexible, strategic responsiveness to threats and opportunities in their changing environments. In situations where contextual features are strong and where local actors have no chance of changing these features, then these actors adapt in response to change. Individual members of the species or group may fail in this task; but the survival of the collective depends on the capacity for flexible adjustment. Whether the challenges are climatic conditions (as in the case of the finches on Daphne Major), international markets (as in European small states), or hungry snakes (as in the case of frogs), the way forward is to develop and deploy rapid response capabilities. As clear evidence of success, we note that finches, frogs and small states continue to exist. They are not extinct. The key distinction between finches and small states is that the changes undergone by the bird in its beak are longer-term and inter-generational; small states are much more supple and flexible, since they are in principle expected to accommodate to change practically all the time. ${ }^{3}$

A similar impression of strategic capability comes across when we zoom in and look critically at individuals who are citizens of small, often island, jurisdictions. In their case, longitudinal studies demonstrate an agile and entrepreneurial responsiveness to shifting opportunities in different stages of their lives. Theirs is a deployment of 'economies of scope', of polyvalency, or of 'occupational multiplicity'-terms that have emerged following research in Caribbean economies such as that by Lambros Comitas (1963) and Richard Frucht (1967). Being "a Jack, or Jill, of many trades" (Bennell and Oxenham, 1983) may not secure the blessing of international observers bred in a context where rigid specialization and core focus is the mantra. ("Learn how to fly", the owl had said to the frog.) But: "in small countries, the best may sometimes be defined in terms of flexibility and breadth, rather than depth" (Brock, 1988, p. 306).

Take occupational multiplicity. The pursuit of several occupations, either simultaneously or successively, and in more than one geographical location, is a natural survival strategy for individuals or households who inhabit areas where employment or revenue opportunities are limited, and more so where they are seasonal or precarious (Frucht, 1967, p. 296; Trouillot, 1988, p. 32). These would typically involve both waged and non-waged labour, petty commodity production, subsistence fishing or farming and home-working. It is a natural defence mechanism, a "security-centred survival algorithm" (Brookfield, 1975, pp. 56-57) and a lucrative tactic in the face of uncertainty; more so if the small economy's experience is typically "hypothermic" (Baldacchino, 2000), experiencing a sequence of stop-go, boom-and-bust, feast-and-famine situations (Looney, 1989, p. 76; Blackman, 1991, p. 1; Pahl, 1984, pp. 46-48; Price, 1988, p. 1; Fergus, 1991, p. 570). By way of 
example, the migration history of the Caribbean Basin supports Carnegie's (1987) thesis that West Indians live by a philosophy of "strategic flexibility" that allows them to take on whatever economic mobility opportunities may become available (e.g. Foner, 2001; Spickard, Rondillo and Hippolite Wright, 2002).

The life-histories of the inhabitants of small jurisdictions, where meticulously documented, reveal a complex juggling of the pros and cons of home and away. Consider, for example, Isaac Caines, from the Caribbean island of St Kitts (profiled in Richardson, 1983, pp. 54-55); Kawagl, from the Melanesian South Pacific (profiled in Brookfield, 1972, pp. 167-168); and Marshy, a street vendor from Kingston, Jamaica (profiled in Wardle, 2002). Each of the three has a broad skill-set, yet would focus on a particular set of tasks at any point in time. Moreover, when looked at longitudinally, each of these individuals demonstrates an uncanny skill repertoire in the economies and temporalities of scope (as against scale), which include entrepreneurship, flexible specialization, public sector employment, and stints abroad. "Flexible specialisation" (e.g. Poon, 1990) and "multi-functionality" (e.g. Farrugia and Attard, 1989) are the key attributes of small, island economies as much as of their constituent citizens, households and firms (Baldacchino and Bray, 2001; Bertram and Poirine, 2007, p. 368; Schmitz, 1989; Sultana, 2006, pp. 26-27). Consider this account by Carnegie (1982, p. 12):

Even people with very secure jobs often have part-time occupations or get training in other trades to develop other marketable skills. One friend in St Lucia who has been with a particular public service department for about 14 years, and held a middle level position in the department, also had a steady extra income from furniture upholstering. During the time that I knew him, he was also taking an accredited course in welding, and wanted to learn refrigerator repairs as well. He was also looking for opportunities to go abroad to study agronomy... It is commonplace to have several sources of income and systematically to maintain each one, even if some may bring in very little cash.

Thus, individuals, households or business units strategically spread their risks, not in spite, but because of the small economy's overall macro-dependence on one or a few, exogenous sources of income. A synchronic 'snapshot' might suggest a precariously specialized economy; however, a diachronic 'video' reveals a dynamic and diversified portfolio.

Mull over the economic yo-yoing of the Caribbean island state of St Lucia, set up as a plantation economy following European discovery. Sugar drove the plantation economy for many decades but was eclipsed by coal (1880s-1930s), which was in turn overtaken by bananas during the 1960s; tourism then surpassed the banana 'green gold' in revenue in 1993 (e.g. Ellis, 2005). With each (often dramatic) ebb of a specific leading sector and the emergence of another, the socio-economy suffers painful dislocation: unemployment and relative poverty set in amongst the losers who are bound to fight against the change of fortune but who-unless the state succumbs to their protectionist demands - are likely to eventually adapt or negotiate an honourable exit strategy: to draw on social or state supports; switch to what is perceived as the next winning horse; and, as is also typical amongst small islanders, opt for exi(s)le (Bongie, 1998) or a stint overseas. 


\section{Critiquing the 'Vulnerability Paradigm'}

Our 'strategic flexibility thesis', as a conceptual point of departure for the analysis of small economies, contrasts sharply with the more popular 'vulnerability approach' that has dominated much recent conventional wisdom (e.g. Briguglio, 1995; Streeten, 1993). The vulnerability paradigm has followed from downbeat views about the presumed inherent non-viability of small states (e.g. Harden, 1985; Plischke, 1977).

The presumption that constraints of small size and geographical separateness render small economies particularly economically 'vulnerable' is both conceptually and empirically unsatisfactory. Conceptually, there are advantages as well as disadvantages to being small and isolated. Empirically, many small economies appear on balance quite robust in a globalizing world. Briguglio's 'vulnerability index' is positively, not negatively, related to per capita income: the more 'vulnerable' the economy, the higher its per capita income (Armstrong and Read, 2005). Armstrong et al. (1998, p. 644), and Easterly and Kraay (2000, p. 2015) agree that small (mainly island) jurisdictions consistently tend to perform economically better than larger (mainly continental) states. Proponents of the vulnerability hypothesis have implicitly conceded the point by introducing a countervailing concept of "resilience", placed in a contradictory dialectical relationship to vulnerability to produce indeterminacy of outcomes (Briguglio et al., 2005).

The problem with the 'vulnerability' approach is that it was from the outset an $a$ priori top-down construction, departing from the supposition that isolation, exposure and small size must imply economic difficulties greater than those faced by larger economies. The relatively strong ex post economic performance of small economies, however, has always suggested that vulnerability has been overplayed. Briguglio et al. call this the "Singapore Paradox": "the seeming contradiction that a country can be highly vulnerable and yet attain high levels of GDP per capita" (2005, p. 27). But that it is a paradox at all is far from obvious. The vulnerabilityversus-resilience paradigm relies heavily on the suggestion that vulnerability is exogenously imposed, whereas resilience is endogenously created as a response. A review of the components of the two indices, however, reveals that exogenous and endogenous elements are found on both sides. The image of vulnerability is no doubt seen as instrumentally useful in the rhetoric of political lobbying and aid justification - although whether this approach has actually delivered tangible results is another matter altogether-but it lacks solid roots in economic reality.

What Briguglio and Streeten might call "vulnerability", therefore, is better characterized as exposure to incentives to adapt. Where adaptation capability is strong, vulnerability calls forth its opposite and thereby strengthens, rather than weakens, small economies.

Briguglio et al. are, however, clearly on target with their new focus on strategic behaviour by both individual economic agents and policymaking elites in the smallisland setting.

The strategic flexibility model departs from the non-viability-vulnerabilityresilience cluster in a number of interrelated ways. Firstly, it starts from a real-life, inductive, 'bottom up' examination of actual behaviour patterns among small states and their citizens; the alternative cluster tends to be prescriptive and deductive, seeking to explain reality 'top down'. Secondly, the strategic flexibility approach 
tends to be more optimistic and hopeful about the innate qualities of small economies and of the individuals and firms that they comprise; for the non-viabilityvulnerability-resilience paradigm, the tone is more guarded, pessimistic, even fatalistic, because the constraints and limitations are deemed to constitute a structural given. Thirdly, the strategic flexibility thesis treats the economic structure of small economies as a matter of proactive behavioural adaptation within the parameters of smallness, isolation and history, rather than of passive response to exogenously set, world market prices (Bertram and Poirine, 2007). Fourthly, 'small states' may still have considerable internal and external capacity: the Scandinavian countries are excellent examples, with their track record of UN military deployment and involvement in international diplomacy (Thorallsson, 2006, pp. 24-25). As Warrington (1998, p. 105) shrewdly remarks, a small state's "governing wits" may well compensate handsomely for any disadvantages that may, legitimately or otherwise, be associated with its small size.

To be fair, small size, combined with islandness and peripherality, can be argued to render small economies particularly exposed to external shocks (e.g. Briguglio, 1995; Streeten, 1993); but vulnerability in the usual sense of the term applies most clearly in the environmental realm, in cases of natural disasters: earthquakes, floods, volcanic eruptions, hurricanes or tsunamis. There is no well-established empirical basis for claiming economic vulnerability. Paradoxically, the often-cited openness to international trade (one of the key components of the vulnerability index), with its associated volatility, is a source of strength rather than weakness for small economies, obliging them to be internationally competitive on open markets and preventing them from collapsing into anarchy or protectionism on economic terms (Alesina and Spolaore, 2003; Armstrong and Read, 2004, pp. 214, 217-218).

Similarly, a "heavy dependence" on transfers from abroad (increasingly remittances, as in the case of Samoa or Tonga, rather than aid) is often perceived as evidence of vulnerability (e.g. Atkins, Mazzi and Easter, 2000, p. 31), but can equally be an indication of success in luring funds, capital and 'rents' from other economies (Kakazu, 1994) and establishing flourishing diasporas. Researchers such as Armstrong and Read (1998, p. 13) have argued that many states have managed to compensate effectively for their small size by "optimal endogenous policy formulation and implementation" and via a successful "international political economy". Many small jurisdictions have deployed their regulatory powers to facilitate favourable trans-border activity: enacting laws and regulations intended and aimed exclusively at individuals and institutions located beyond their borders (Conrad, 1973, p. 633, our emphasis).

These arguments can be classified schematically as Table 1 below.

\section{Reviewing Pertinent Statistics}

Thus, on balance, small economies appear quite robust in a globalizing world. Take the annual economic review of Commonwealth small states, which compares vital statistics of the 35 Commonwealth jurisdictions with similar values for 28 other countries, all collated from World Bank data. In terms of GDP per capita, Gambia, Guyana, Lesotho and Sierra Leone are the only Commonwealth small states considered to be low-income economies. All but one is located in Africa, the main 
Table 1. The 'strategic flexibility' versus 'vulnerability' approach to the performance of small economies: the paradigms compared, issue by issue

\begin{tabular}{|c|c|c|}
\hline Issue & Strategic flexibility approach & Vulnerability approach \\
\hline Grounding & $\begin{array}{l}\text { Based on 'bottom up', } \\
\text { empirical observation } \\
\text { (inductive) }\end{array}$ & $\begin{array}{l}\text { Based on prescriptive, } \\
\text { 'top-down' construction } \\
\text { (deductive) }\end{array}$ \\
\hline Tone & $\begin{array}{l}\text { Optimistic, strategic (room for } \\
\text { agency) }\end{array}$ & $\begin{array}{l}\text { Pessimistic, deterministic } \\
\text { (dictated by structures) }\end{array}$ \\
\hline $\begin{array}{l}\text { Scope of } \\
\text { vulnerability }\end{array}$ & $\begin{array}{l}\text { Limited to environmental } \\
\text { hazards }\end{array}$ & $\begin{array}{l}\text { Wide-ranging: includes } \\
\text { economic and } \\
\text { environmental hazards }\end{array}$ \\
\hline $\begin{array}{l}\text { Smallness and } \\
\text { isolation/ } \\
\text { islandness/ } \\
\text { remoteness }\end{array}$ & $\begin{array}{l}\text { Offer advantages and } \\
\text { disadvantages }\end{array}$ & $\begin{array}{l}\text { Are inherent disadvantages } \\
\text { (including diseconomies } \\
\text { of scale) }\end{array}$ \\
\hline Income per capita & $\begin{array}{l}\text { Greater openness = higher } \\
\text { income }\end{array}$ & $\begin{array}{l}\text { Greater openness = lower } \\
\text { income }\end{array}$ \\
\hline $\begin{array}{l}\text { Performance of } \\
\text { smaller } \\
\text { economies } \\
\text { compared to } \\
\text { larger ones }\end{array}$ & $\begin{array}{l}\text { Smaller economies perform } \\
\text { better }\end{array}$ & $\begin{array}{l}\text { Explained by high resilience } \\
\text { or 'paradoxes' }\end{array}$ \\
\hline $\begin{array}{l}\text { Nature of } \\
\text { vulnerability }\end{array}$ & $\begin{array}{l}\text { Better understood as exposure } \\
\text { to incentives to adapt }\end{array}$ & $\begin{array}{l}\text { Imposed as a structural } \\
\text { 'given' }\end{array}$ \\
\hline $\begin{array}{l}\text { Economic } \\
\text { structure of } \\
\text { small economies }\end{array}$ & $\begin{array}{l}\text { Proactive behavioural } \\
\text { adaptation }\end{array}$ & $\begin{array}{l}\text { Reactive response to } \\
\text { exogenously-set price } \\
\text { signals }\end{array}$ \\
\hline Capacity & Inherent & $\begin{array}{l}\text { Needs to be 'built' and } \\
\text { 'nurtured' }\end{array}$ \\
\hline $\begin{array}{l}\text { Openness to } \\
\text { international } \\
\text { trade }\end{array}$ & $\begin{array}{l}\text { Source of strength and } \\
\text { competitiveness }\end{array}$ & $\begin{array}{l}\text { Source of powerlessness and } \\
\text { weakness }\end{array}$ \\
\hline $\begin{array}{l}\text { Dependence on } \\
\text { transfers from } \\
\text { abroad }\end{array}$ & $\begin{array}{l}\text { Source of strength and } \\
\text { competitiveness }\end{array}$ & $\begin{array}{l}\text { Source of powerlessness and } \\
\text { weakness }\end{array}$ \\
\hline
\end{tabular}

geographic location of the world's poorest and least developed states. At the other end of the scale, the six Commonwealth small states that are high-income economies are all either islands in toto, or on islands: the Bahamas, Brunei, Cyprus, Malta, New Zealand and Singapore (Commonwealth Secretariat, 2005, Table 4). The poorest economies have the largest contributions by agriculture to overall GDP, typically, $20-60 \%$, whereas the richest small economies have no agricultural sector worth noting (Singapore $=0 \%$; Malta and Bahamas $=3 \% ; \quad$ Brunei $=5 \%$; New Zealand $=5 \%$; Cyprus $=7 \%$, as at 2003) (Commonwealth Secretariat, 2005, Table 5). ${ }^{4}$ It has been argued that a strong agricultural lobby tends to brake an economy from industrialization and economic diversification. Streeten (1993, p. 199) calls the agricultural lobby a "slowcoach" to development. To the extent that this is correct, the absence of a rural hinterland is potentially good news for development. ${ }^{5}$

Consider next the grouping of small developing states by region and by levels of human development (as measured by the UNDP using 2000 data), including 
indicators such as life expectancy at birth, adult literacy, gross primary secondary and tertiary enrolment, and GDP per capita at purchasing power parity. Ten small economies-Barbados, Bahamas, Antigua and Barbuda, Brunei, Bahrain, Malta, Cyprus, Bhutan, Qatar and Estonia - have the highest human development levels. At the other end, there are just three small economies with low levels of human development: Djibouti, Gambia and Guinea-Bissau (Liou and Ding, 2002).

Out of the World Bank's list of 44, high-income, non-OECD countries, all but one (Saudi Arabia) are small economies (e.g. Davies et al., 2006, Appendix V). ${ }^{6}$ Out of the large number of Caribbean island states and sub-national island jurisdictions, the World Bank only considers Cuba, the Dominican Republic, Jamaica and St Vincent and the Grenadines as "lower middle income economies", while Haïti is the only Caribbean nation to appear as a "lower income economy". It is pertinent to note that four out of the five countries in this unenviable grouping are the largest (that is, most heavily populated) economies in the region. The exception, St Vincent and the Grenadines, is still reeling from the uncertainty surrounding the future of bananas, its main export crop, and painfully making the switch to other economic activities, particularly tourism and construction (Caribbean Development Bank, 2005).

It may come as a surprise that a listing of the 10 richest countries of the world in terms of GDP per capita according to the World Bank would feature only two 'large states': Japan and the USA. The other eight have populations of less than 10 million each, and three have populations of less than one million. Liechtenstein holds the top spot, followed by Luxembourg (e.g. www.quia.com/rd/6913.html). It appears much more pertinent to contemplate the challenges of 'giantism' (e.g. Lewis, 1991, on India) and the anomalous success of large countries like the US (e.g. The Economist, 2003), than to assume that small jurisdictions are inherently disadvantaged.

The above discussion is predicated on the suitability of GDP per capita (typically based on purchasing power parity) as the choice indicator of comparison. However, and in spite of its universal availability, the statistic has its limitations (for example, it emphasizes a territorial, rather than national, approach). Small economies tend to be badly served by GDP-based analysis, which is a source of both under-evaluations and over-evaluations. Added transport costs (a consequence of islandness and remoteness) and public aid (designed to offset the consequences of islandness and remoteness) are both considered as 'wealth' produced in the region and thus increase GDP. On the other hand, extensive social networking, occupational multiplicity, rich levels of bridging and bonding 'social capital' and voluntarism mean that the citizens of various small jurisdictions perform 'activities' that either do not feature in official value added, or else mitigate (via preventive measures) what would otherwise be registered as 'expenditure' (such as family-based child or elderly care). Some such activities may be remunerated; others may be compensated in kind; others still may be for personal use (e.g. Baldacchino, 2005a).

Various other activities are designed to exploit the resources of the sprawling public sector: working the system and the state for economic gain is a viable intrapreneurial strategy in small polities, because decision-makers are known and accessible, and decision-making is a transparent process (Lowenthal, 1987, p. 43; Schahczenski, 1992, p. 41).

Finally, but just as importantly, a stock of overseas-resident migrants sustains a flow of remittance transfers that can constitute a significant, legitimate and regular 
provision of foreign exchange (Prasad, 2004, pp. 51-53). Remittance providers can be depended upon for the provision of cash and/or gifts in kind for a limited time period, after which they may be replaced or refreshed with new emigrants who would kick-start the process once more, in a cycle that represents a shrewd incomemaximization strategy by a household that functions as a fully fledged "transnational corporation of kin" (Marcus, 1981). The incentive to perform such tasks increases with higher levels of taxation (typical of small island states with narrow tax bases) since all these activities typically escape the conventional tax net. In sum, then, the citizens of small economies tend to have better living standards than their GDP figures suggest.

The existence, and ongoing reproduction via migration, of large diasporas of small state citizens carries the implication that migrants experience higher levels of real income than home residents. Recent IMF work on the concept of "Gross MigrationAdjusted Product" (GMP) (Ueda, 2002; Cardarelli and Ueda, 2004) suggests that the territorially restricted frame of reference of conventional national-income accounting fails to capture much of the actual economic growth experience of internationally mobile populations of the sort typified by small economies.

Even though the per capita GDP of small states is much higher on average than that of other less developed countries, the former have received as much as almost nine times as much aid per capita on average when compared to other less developed states: US\$87 as against US\$10. Moreover, sub-national or non-sovereign island jurisdictions receive 36 times more bilateral aid than comparable independent island states: US\$3099 per capita (Poirine, 1999, p. 843, Table 1). Meanwhile, development aid is fast being outstripped by migrant worker remittances, now the largest single category of international financial flows to small states (Bertram and Poirine, 2007, pp. 348-353).

\section{Towards a Taxonomy of the Structures of Small Economies}

In a number of small jurisdictions, cash incomes are derived to a large extent from migrant remittances and public sector employment, the latter supported by international aid flows. This condition crowds out economic activity in the conventionally 'productive' private sector. A high propensity to migrate represents a rational development option (in spite of its prima facie unorthodoxy) not merely for the individual migrants, their households and their businesses, but also for the economy as a whole. The 'MIRAB' structure, ${ }^{7}$ originally applied to five small Pacific territories, ${ }^{8}$ can be extended to other small jurisdictions; Haiti is the single most obvious contemporary MIRAB state in the Caribbean, along with Dominica.

But MIRAB is only one of the patterns of the kaleidoscope (Bertram, 2006, p. 11). Especially in the Caribbean, international tourism plays a considerable role, to such an extent, that apart from public sector employment, many small economies are driven by the tourism industry. McElroy (2006; also Oberst and McElroy, 2007) calls these Small Island Tourism Economies (SITEs), and he argues that they constitute a "special island development alternative" to MIRAB. Although the costs as well as benefits of tourism have long been well recognized (e.g. Bryden, 1973), McElroy argues that SITEs tend towards a distinctive profile: they are inclined to be more affluent, and their citizens enjoy higher mobility, higher life expectancy, higher 
literacy, lower fertility and lower infant mortality rates. The world's most tourism penetrated economies are concentrated in the Caribbean; they are all small and islanded, and they tend to be sub-national island jurisdictions. ${ }^{9}$ The Caribbean tourism product has been developed in the context of international competition and free trade, benefits from a distinctive regional brand, and boasts two locally owned flagship hospitality multinationals in Sandals (www.sandals.com/) and Superclubs (www.superclubs.com/).

Beyond tourism, remittances and aid, there are a raft of other 'economic capacities' that small economies can deploy, given good governance, the creative use of jurisdiction as a resource, durable ties to a larger political host, and some measure of good luck: either singly or in combination, and often in association with tourism (Baldacchino and Milne, 2006). These capacities can include: offshore banking and related financial services; niche-targeted, well branded manufactures; cultural and natural heritage assets; air and sea transportation; citizenship, residency and work permits; and paradiplomacy. Activities such as these do not become growth poles on their own: they are nurtured and often initiated by active strategic behaviour on the part of the jurisdictional elite. Current exemplars of such successful small economies would include the states of Cyprus, Malta, Mauritius, and the Seychelles; and the Sub-National Island Jurisdictions (SNIJs) of Åland, Aruba, Bermuda, Cayman and the Falkland Islands. The acronym for such economies would spell PROFIT ${ }^{10}$ (Baldacchino, 2006, p. 54).

Baldacchino (2006) argues that PROFIT economies differ from their MIRAB cousins in their more explicit collective focus on negotiation and protection of their chosen niches: a shrewd immigration and cyclical migration policy; tough external negotiations concerning the use of local mineral, natural, political and other imaginative but exploitable resources; securing and controlling viable means of transportation; and luring foreign direct investment via preferential tax regimes.

SITE economies intersect clearly with both MIRAB and PROFIT economies; while MIRAB and PROFIT economies have fewer intersections (see Figure 1).

The broader the clutch of capacities successfully deployed, the less the respective dependence on any particular economic sub-sector; but diversification in very small scale settings is not necessarily a good thing, and can weaken the strategic focus on the growth pole. Bertram and Poirine (2007, pp. 329-330) comment thus:

Below a size threshold somewhere around the 1-million population mark, economies (including landlocked ones such as the Vatican as well as islands) tend to exhibit extreme specialisation into one or two globally-linked leading sectors which, once selected, determine the character of the economy as a whole. The selection process obeys not so much the orthodox theory of comparative advantage (in which an economy responds in passive fashion to exogenous relative-price signals) as a strategic game-theoretic process of self-selective hyper-specialisation, here labeled 'speciation'... 'Speciation' refers to the sort of specialisation in which an entire community takes advantage of a niche of evolutionary opportunity by adopting a particular economic 'personality' with its own distinctive set of institutions, policy imperatives, and mutual understandings amongst the participating population. Economic speciation involves a conscious or quasi-conscious collective decision by the [small state] community 


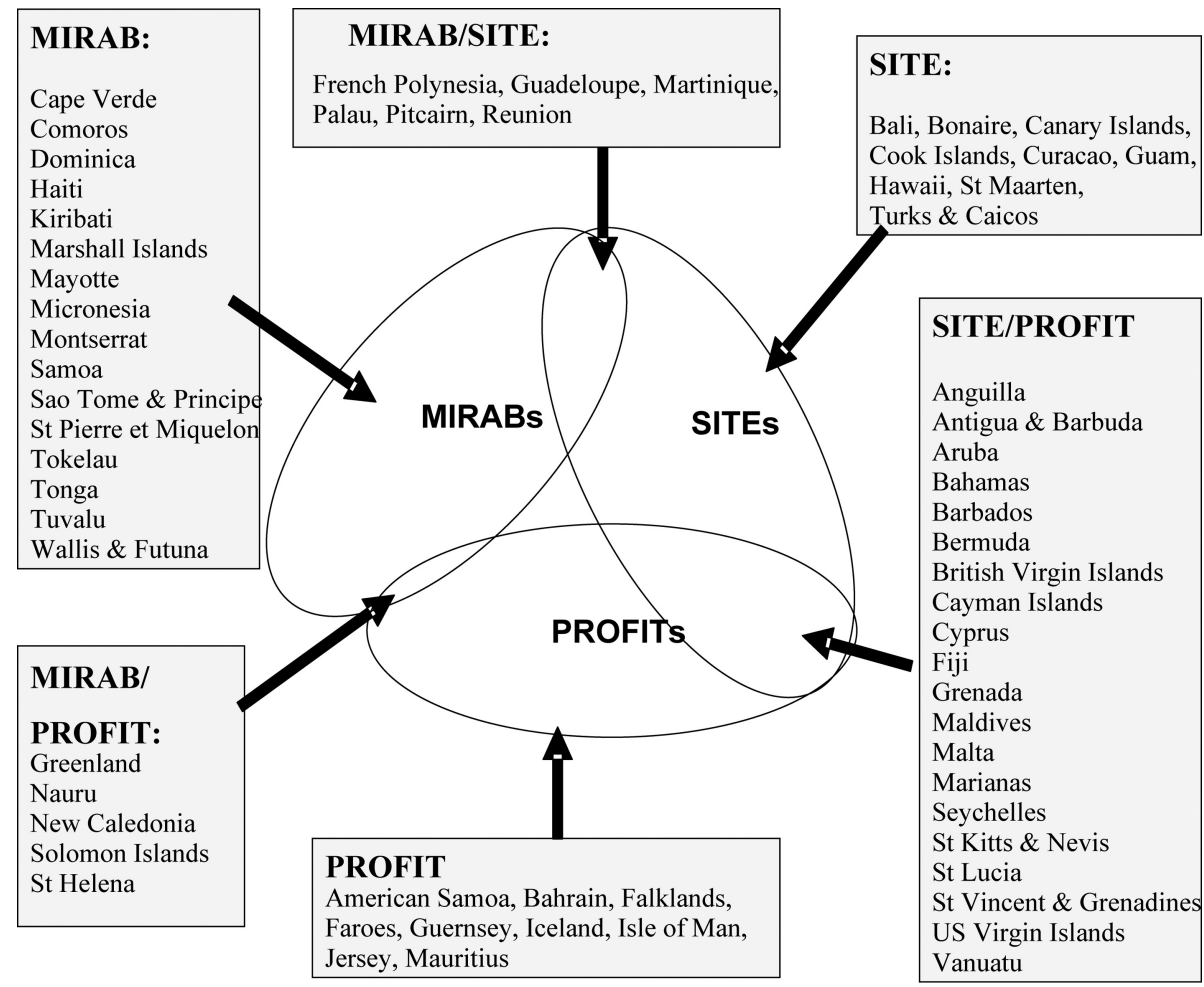

Figure 1. The structures of small economies: a threefold taxonomy (with overlaps). Sources: Adapted from Bertram (2006) and Bertram and Poirine (2007).

to embrace the economic phenomenon of crowding-out, with 'Dutch Disease' treated as an evolutionary opportunity rather than a threat. (Matsen and Torvik, 2005)

Given the openness of small economies to events beyond their control, and the likely high impact of any such events on the domestic economy, one should not be surprised to find evidence of dynamism: particular economies mutate as their environments shift. When a longitudinal perspective is adopted, the economies of small states tend to move in and out of a specific cluster. An increase or decrease in tourism; more or less aid provision; the success or failure of a key private industry or sub-sector (like fisheries or banking), can oblige a small economy to move (often quite swiftly) out of one cluster and into another. This dynamic flexibility and "rapid response capability" (Bertram and Poirine, 2007, p. 333) is a strategic (although it could also be a default) response to opportunity, especially necessary in situations where there is hyper-specialization of economic activity at a national level. East Timor, Nauru and the Comoros have increasingly taken on the character of MIRAB states in recent years; the Cayman Islands have moved away from being a MIRAB classic to a PROFIT/SITE success story; São Tomé y Principe is slated to move from MIRAB to PROFIT as it transits to an oil-exporting economy. 
To allow space in the story for believers in the one-dimensional conventional development paradigm, nurturing successful indigenously owned, small-scale, export-oriented manufacturing firms in small economies may be difficult but is not impossible: the typically largest indigenous manufacturing firm in many small economies is a brewery, serving a mainly local market. Manufacturing products which benefit from locally available, raw material input can be viable business ventures, especially if there is: a strong branding of the product with the respective island and its associated characteristics; free-riding on tourism; and limited local firm rivalry (Baldacchino, 2005b; Fairbairn, 1988; Punnett and Morrison, 2006). There are also a few examples of remarkable success in export-oriented manufacturing on the back of jurisdiction-specific institutional opportunities: export-processing zones in Mauritius (Subramaniam and Roy, 2001), garment manufacturing for the US market in the Northern Marianas, where cheap Asian migrant workers can be recruited outside the US visa border but the production occurs inside the US customs frontier (Bertram and Poirine, 2007, pp. 333-334).

Finally, in the information and communication technology sector, firms from small states can compete in export markets without most of the handicaps associated with islandness and remoteness, developing products or services that are light or which, like software, have no tangible weight or volume and which can be procured and serviced electronically. In any case, island entrepreneurs can develop and nurture 'extra-island' contacts and markets to usurp the limitations of the domestic market using, for example, diaspora links (e.g. Camara, 2006; Baldacchino and Fairbairn, 2006). The absence of notable local market opportunities induces small state entrepreneurs to "export or perish", obliging a competitive strategy from inception (Baldacchino and Vella Bonnici, 2006).

\section{Shopping Around for the Right Role Models}

What then leads some small countries to rely on aid and/or remittances, while others (Malta, Ireland) have even shed their status as developing countries? There is no simple or single answer to this question, but the strategic perceptions of key individuals can be crucial in small jurisdictions. A common theme is the quest for useful role models, in the hope of identifying the key ingredients in proven recipes. Historically, Singapore's leadership held Malta as a role model in the 1960s (Lee Kwan Yew, 2000); while Mauritius in the early 1970s held Taiwan and Puerto Rico as its prime examples of how to succeed in reinventing itself as an export-processing zone (Yeung Lam Ko, 1998, p. 7). Imitation has its limitations, however: it is too easy to forget that many recipes for success are historically specific (path-dependent) and cannot be easily replicated. Under the right particular circumstances, and the right frame of mind, what may appear to be a liability - like ethnic diversity - may end up proving to be an asset.

Warrington and Milne (2007) propose a typology consisting of seven patterns of island governance, based on a critical, historical review of small island development. Many of these patterns will be easily recognized since they have been deployed by social scientists to describe a distinguishing feature which becomes the dominant signature, or leitmotif, of a particular island's existence. This typology includes the pattern called plantation, which is associated by scholarship with the bulk of 
Caribbean small states; the fief is associated with Haiti; the settlement with Iceland; and the fortress with Malta. The typology also includes the entrepot (literally, a trading centre): "a market enjoying the fortress's advantages of location and centrality, but generating internally the conditions fostering its success: specifically investment finance, entrepreneurial flair as well as a legal, regulatory and dispute resolution regime that facilitates market transactions and innovation by minimizing cost and risk" (Warrington and Milne, 2007, p. 413, emphasis in original). Many small economies have started off with the political economy of fiefs, fortresses, settlements or plantations, and have charted their emancipation from this condition by the entrepôt star. $^{11}$

Of course, being an entrepôt does not change an economy's small size and its geography. Any small entrepôt economy remains prone to such contingencies as regional wars, natural disasters, accidents, security threats, epidemics, market shocks or technological obsolescence. Lacking a hinterland under its own control, it cannot count on material, fiscal or even human resource reserves available to larger countries. ${ }^{12}$ Unless an entrepôt tirelessly innovates, re-positions and reinvents itself and enhances its competitiveness, it is always at risk of decline. The innovative streak concerns not only product development and technological sophistication, but extends beyond, to creative governance. This includes the recognition of the resourcefulness of jurisdictional capacity, using the leverage that it provides on the international stage to secure concessionary bilateral trade agreements, build and nurture special relationships with benevolent patrons; while making the domestic economy attractive for business, with government and public administration supporting vigorous economic activity, quality education and welfare schemes. Entrepôts tend towards conservative rather than liberal democracy, emphasizing consensual politics and mistrusting dissent. Their necessary openness to, and engagement with, the outside world is a shared development paradigm across the political divide. If they attract immigrants and their various cultures, then their outward cultural assimilation is favoured (Warrington and Milne, 2007, passim). Mauritius exemplifies both the problem and the strategy (e.g. Chernoff and Warner, 2002).

\section{Conclusion: Strategy and Context; Agency and Structure}

The triple accidents of size, geography and sovereignty have endowed many small economies with: an element of cultural cohesion; a relatively large and ubiquitous public sector; a disproportionate presence in international affairs; rich social networks with commensurate levels of social capital; an extensive and relatively affluent diaspora; and, especially in the temperate and tropic regions of the world, a disposition to become tourist attractions.

These characteristics can be complemented or fleshed out by a range of possible economic activities. The latter would include: geo-strategic rents; niche 'high-end' banking and offshore finance services; niche high value-added export manufactures; cash crops, minerals, fish and other 'natural resource rents' that command competitive prices on open markets; other 'rents' derived via negotiation with metropolitan powers (mainly grants and loans, but also special prices on certain exports); high economic return migration via the international mobility of domestic 
labour and transfers via remittances or repatriated capital; and conventional rents resulting from property sales to expatriates or returning migrants that have large multiplier effects on the local economy. ${ }^{13}$ Not all of these can be pursued at the same time: aid and remittances, for example, tend to 'crowd out' other activities. But some can: a combination of offshore finance and high quality tourism stands out as the strategy of the most successful island economies today (Bertram and Poirine, 2007, p. 362).

The situation can be visually represented as a series of options laid out on a spinning wheel. There is thus a range of economic options available, each represented by a segment, whose importance will ebb and flow through time, as they become more and less important historically. Whether the small economy corresponds to the MIRAB, SITE or PROFIT model would now be seen to largely depend on which are the leading economic sectors (see Figure 2).

The operating context being what it is, one or more of these options may shrivel or disappear suddenly; this is the price to be paid for economic openness. But when that happens, the strategically flexible economy repositions and regroups, investing more in existing competencies or sourcing new ones in pursuit of an optimal portfolio for the new conjuncture. As denoted by the Caribbean expression: "If you lose the dog, grab the cat". ${ }^{14}$ Back to our Galápagos finch: just like a finch, the basic beak physiognomy remains unchanged: the same goes for the small island economy's key

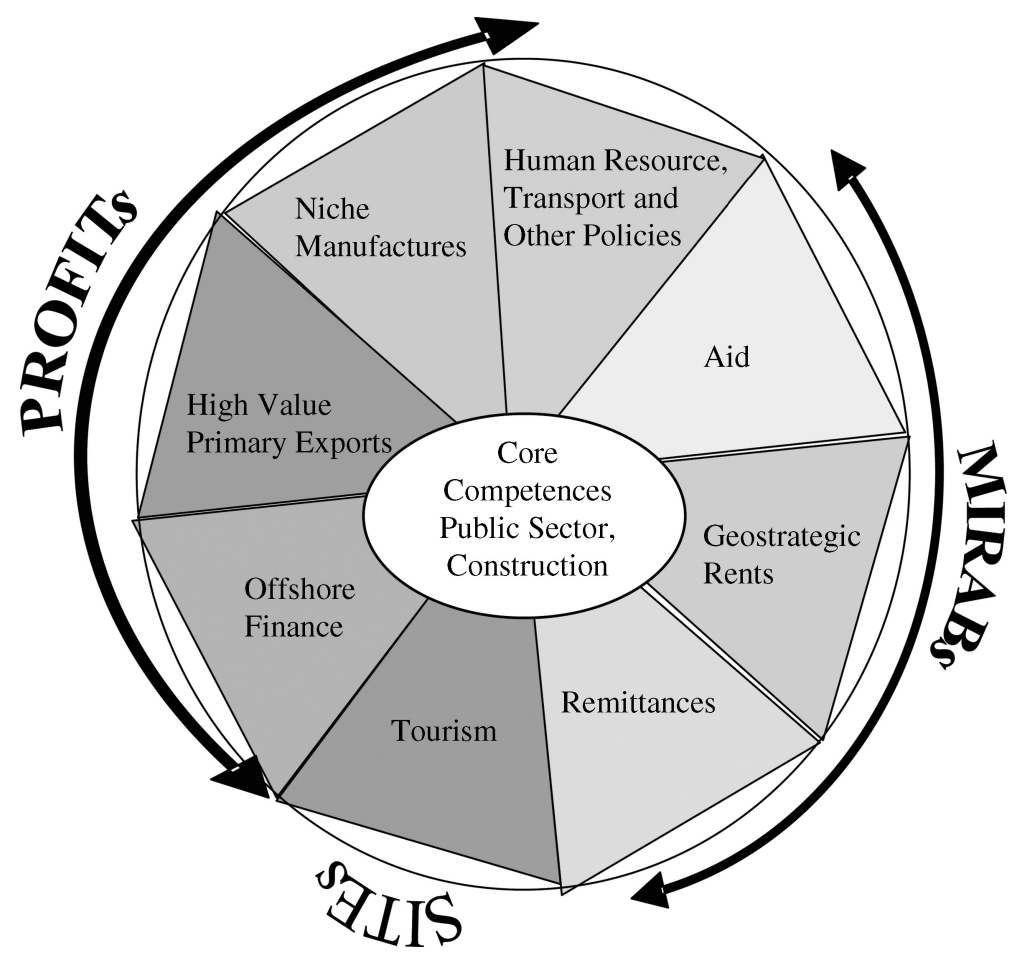

Figure 2. Spinning the wheel: the structures of small economies. 
enduring characteristics. But, unlike the finch, and even better than the Aesopian frog, small, often island economies have the added capacity to refashion their beaks in response to actual or potential environmental opportunity.

This is not to say that all small economies are successful. Haiti in the Caribbean, and the Solomon Islands, Vanuatu and Timor Leste in the Pacific, represent islands or quasi-islands where the rule of law has collapsed in recent years, or where economies have been prone to gross mismanagement-they now have the unenviable status of being referred to as "failed states'. ${ }^{15}$ The sovereign state of Nauru, in particular, once a phosphate nugget hailed as the richest per capita country in the world, has been acting much like a fief of Australia (e.g. Connell, 2006). But, as has been argued earlier, the general global picture for small (mainly island) states is positive. That for non-sovereign (mainly island) jurisdictions is even better.

This article is a (long overdue) response to the vulnerability literature, and is very much an actor-driven assessment of small economies and their citizens, presenting them as strategically securing their place in the world. They do so by making choices, even as those choices are curtailed or reduced because of history, geography, resource restrictions and happenstance. Our approach will hopefully bring in some fresh air to a debate that has been dominated far too long by structural determinism, wherein smallness, islandness and remoteness only feature as handicaps that somehow need to be overcome or compensated for. We have put forward a strategic flexibility model, both as counterpoint to the vulnerability one, and as an alternative and coherent theoretical model for the study of small, often island, economies.

To conclude, it appears useful to pitch in another quote, this time from the unlikely source of Karl Marx, one that positions human agency within historical realism:

Men [sic] make their own history, but they do not make it as they please; they do not make it under self-selected circumstances, but under circumstances existing already, given and transmitted from the past. (Marx, 1852, chapter 1, emphasis added)

\section{Acknowledgements}

Earlier drafts of this paper were presented at the First International Conference on the Articulation of a Development Paradigm for the Member States of the Organization of Eastern Caribbean States, Rodney Bay, St Lucia, January 2007, and at the Commonwealth Secretariat-University of Malta Conference on Small States and Economic Resilience, Valletta, Malta, April 2007. The authors thank Harvey W. Armstrong and Naren Prasad and various anonymous referees for encouraging comments on an earlier draft. The usual disclaimers apply.

\section{Notes}

1. We understand smallness to be essentially an arbitrary term, and we are aware that the world's current median sovereign state population is 5.3 million (represented by Finland). We also note that the Commonwealth Secretariat (ComSec) has adopted a working definition of small states to comprise those with resident populations of less than 1.5 million. However, recent ComSec literature 
(e.g. Qureshi and te Velde 2008; ComSec 2006) seems willing to adopt an upper threshold of five million population (thus including Singapore).

2. Though not included by Katzenstein, Ireland (1987-2005), with its own experience of corporatism (e.g. Walsh, 2004, pp. 279 et seq.), would fit comfortably within this list. There are, however, other explanations for the 'Celtic Tiger' phenomenon.

3. Were finches as supple and flexible as small states, the birds would be able to change the shape and size of their beak practically at will, something that evolution does not (yet?) allow to happen.

4. New Zealand is nevertheless a major exporter of pastoral commodities, whose processing and transportation accounts for a larger share of GDP.

5. Again, New Zealand is to some extent the exception that proves this rule: an economy whose rural hinterland has always been highly developed, technologically sophisticated, and globalized in outlook. Even there, farmers have generally been a conservative political voice, but their influence has waned since the 1950s.

6. Full dataset available at: http://siteresources.worldbank.org/DATASTATISTICS/Resources/CLASS. XLS.

7. Migration, Remittances, Aid and Bureaucracy (Bertram and Watters, 1985).

8. These are: Cook Islands, Kiribati, Niue, Tokelau and Tuvalu.

9. Aruba, Cayman Islands, Sint Maarten and the UK Virgin Islands have the highest tourism penetration index scores (based on 2003 data). McElroy (2006, p. 72, Table 6).

10. Personal considerations affecting citizenship, residence and employment rights; Resource Management; Overseas engagement and ultra-national recognition; FInance and Transportation.

11. The two other 'signatures' identified by Warrington and Milne (2007) are the civilization and the refuge.

12. Witness, for example, the 'water wars' between Singapore and Malaysia (Sparke et al., 2004).

13. For an early study of this phenomenon, see King and Strachan (1980) on Gozo.

14. In St Lucian Creole: Mantche shien, pwen shat (see Carnegie, 1982, p. 11).

15. A Failed States Index was initiated in 2004. See: http://www.foreignpolicy.com/story/cms.php? story_id=3098. The current global recession may herald another category of fiscally failed states, starting with Iceland.

\section{References}

Alesina, A. and Spolaore, E. (2003) The Size of Nations (Cambridge, MA: MIT Press).

Armstrong, H. W. and Read, R. (1998) The International Political Economy of Micro-states: An Overview. Paper presented at Islands $V$ Conference, Mauritius, University of Mauritius, July.

Armstrong, H. W. and Read, R. (2004) Small states and island states: implications of size, location and isolation for prosperity, in J. Poot (Ed.), On the Edge of the Global Economy (Cheltenham: Edward Elgar), pp. 191-223.

Armstrong, H. W. and Read, R. (2005) Insularity, remoteness, mountains and archipelagoes: a combination of challenges facing small states? Asia Pacific Viewpoint, 47(1), pp. 79-92.

Armstrong, H. W., De Kervenoael, R. J., Li, X. and Read, R. (1998) A comparison of the economic performance of different micro-states, and between micro-states and larger countries, World Development, 26(3), pp. 639-656.

Atkins, J. P., Mazzi, S. and Easter, C. D. (2000) A Commonwealth Vulnerability Index for Developing Countries: The Position of Small States (London: Commonwealth Secretariat).

Baldacchino, G. (2000) The challenge of hypothermia: a six-proposition manifesto for small island territories, The Round Table: Commonwealth Journal of International Affairs, 89(353), pp. 65-79.

Baldacchino, G. (2005a) The contribution of social capital to economic growth: lessons from island jurisdictions, The Round Table: Commonwealth Journal of International Affairs, 94(378), pp. 35-50.

Baldacchino, G. (2005b) Successful small scale manufacturing from small islands: comparing firms benefiting from local raw material input, Journal of Small Business and Entrepreneurship, 18(1), pp. 21-38.

Baldacchino, G. (2006) Managing the hinterland beyond: two, ideal-type strategies of economic development for small island territories, Asia-Pacific Viewpoint, 47(1), pp. 45-60.

Baldacchino, G. and Bray, M. (Eds) (2001) Human resource issues in small states, International Journal of Educational Development, 21(3), pp. 203-291, special issue. 


\section{G. Baldacchino and G. Bertram}

Baldacchino, G. and Fairbairn, T. I. J. (Eds) (2006) Entrepreneurship and small business development in small islands, Journal of Small Business and Entrepreneurship, 19(4), pp. 331-430, special issue.

Baldacchino, G. and Milne, D. (Eds) (2006) Special issue dedicated to sub-national island jurisdictions, The Round Table, 95(386), pp. 487-626.

Baldacchino, G. and Vella Bonnici, J. (2006) Successful Small Business from Small Islands: A Training Manual (Luga, Malta: Malta Enterprise).

Bennell, P. and Oxenham, J. (1983) Skills and qualifications for small island states, Labour and Society, 8(1), pp. 3-38.

Bertram, G. (Ed.) (2006) Special issue commemorating the 20th anniversary of the MIRAB concept, Asia Pacific Viewpoint, 47(1).

Bertram, G. and Poirine, B. (2007) Island political economy, in G. Baldacchino (Ed.), A World of Islands: An Island Studies Reader (Charlottetown, Canada and Luga, Malta: Institute of Island Studies and Agenda Academic), pp. 325-378.

Bertram, G. and Watters, R. F. (1985) The MIRAB economy in South Pacific microstates, Pacific Viewpoint, 26(3), pp. 497-519.

Blackman, C. N. (1991) The economic management of small island developing countries, Caribbean Affairs, 4(1), pp. 1-12.

Bongie, C. (1998) Islands and Exiles: The Creole Identities of Post/Colonial Literature (Stanford, CA: Stanford University Press).

Briguglio, L. (1995) Small island developing states and their economic vulnerabilities, World Development, 23(9), pp. 1615-1632,

Briguglio, L., Cordina, G., Farrugia, N. and Vella, S. (2005) Conceptualizing and measuring economic resilience, in S. Chand (Ed.), Pacific Islands Regional Integration and Governance (Canberra: Australian National University Press), pp. 26-49.

Brock, C. (1988) Education and national scale: the world of small states, Prospects, 18(3), pp. 303-314.

Brookfield, H. C. (1972) Colonialism, Development and Independence: The Case of the Melanesian Islands in the South Pacific (Cambridge: Cambridge University Press).

Bryden, J. M. (1973) Tourism and Development: A Case Study of the Commonwealth Caribbean (Cambridge: Cambridge University Press).

Cardarelli, R. and Ueda, K. (2004) Domestic and global perspectives of international migration to the United States, in United States: Selected Issues, IMF Country Report 04/228.

Camara, F. (2006) Export and social networking as a resource control strategy: a case study from the Azores, Journal of Small Business and Entrepreneurship, 19(4), pp. 395-408.

Caribbean Development Bank (2005) St Vincent and the Grenadines: Annual Economic Review 2005. www.caribank.org/Publications.nsf/EReview2005_stvincent/\$File/ECReview2005_stvincent.pdf?Open Element.

Carnegie, C. V. (1982) Strategic flexibility in the West Indies: a social psychology of Caribbean migration, Caribbean Review, 11(1), pp. 10-13, 54.

Carnegie, C. V. (1987) A social psychology of Caribbean migrations: strategic flexibility in the West Indies, in B. B. Leine (Ed.), The Caribbean Exodus (New York: Praeger), pp. 32-43.

Charles, E. et al. (1997) A Future for Small States: Overcoming Vulnerability (London: Commonwealth Secretariat).

Chernoff, B. and Warner, A. (2002) Sources of Fast Growth in Mauritius: 1960-2000. Paper prepared for conference on Iceland in the World Economy: Small Island Economies in the Era of Globalisation, Boston MA, Harvard University.

Comitas, L. (1963) Occupational multiplicity in rural Jamaica. Proceedings of the 1963 Annual Spring Meeting of the American Ethnological Society, Seattle WA, pp. 41-50. Reprinted in L. Comitas and D. Lowenthal (Eds) (1973) Work and Family Life: West Indian Perspectives (New York: Anchor Press/ Doubleday), pp. 157-173.

Commonwealth Consultative Group (1985) Vulnerability: Small States in the Global Society-Report of a Commonwealth Consultative Group (London: Commonwealth Secretariat).

Commonwealth Secretariat (ComSec) (no date) Measuring Vulnerability. http://www.thecommonwealth. org/Internal/140457/153059/153060/measuring_vulnerability/.

Commonwealth Secretariat (ComSec) (2005) Small States: Economic Review and Basic Statistics. Vol. 10 (London: Commonwealth Secretariat). 
Commonwealth Secretariat (ComSec) (2006) Small States: Economic Review and Basic Statistics. Vol. 11 (London: Commonwealth Secretariat).

Connell, J. (2006) Nauru: the first failed Pacific state? The Round Table: Commonwealth Journal of International Affairs, 95(363), pp. 47-63.

Conrad, A. F. (1973) An overview of the laws of corporations, Michigan Law Review, 4, pp. 623-690.

Crowards, T. and Coulter, W. (1998) Economic Vulnerability in the Developing World with Special Reference to the Caribbean (Barbados: Caribbean Development Bank).

Crowards, T. and Coulter, W. (1999) An Economic Vulnerability Index for Developing Countries, with Special Reference to the Caribbean: Alternative Methodologies and Provisional Results (Barbados: Caribbean Development Bank).

Davies, J. B., Sandstrom, S., Shorrocks, A. F. and Wolff, E. N. (2006) The World Distribution of Household Wealth, paper presented at the WIDER Project Meeting on Personal Assets from a Global Perspective, Helsinki, 4-6 May, available at: http://repositories.cdlib.org/cgi/viewcontent.cgi?article= $1068 \&$ context $=$ cgirs.

Easterly, E. and Kraay, A. C. (2000) Small states, small problems? Income, growth and volatility in small states, World Development, 28(11), pp. 2013-2027.

The Economist (2003) When small is beautiful. The Economist Intelligence Unit, 20 December, p. 108.

Ellis, G. (2005) St Lucia's declining banana trade, BBC News, 2 August. http://news.bbc.co.uk/1/hi/world/ americas/4737473.stm.

Fairbairn, T. I. J. (1988) Indigenous entrepreneurship and business development in the Cook Islands, in T. I. J. Fairbairn (Ed.), Island Entrepreneurs: Problems and Performance in the South Pacific (Honolulu: East West Center), pp. 55-76.

Farrugia, C. J. and Attard, P. A. (1989) The Multifunctional Administrator (London: Commonwealth Secretariat).

Fergus, H. E. (1991) The challenge of educational reform in microstates: a case study of the Organisation of Eastern Caribbean States, Prospects, 21(4), pp. 561-571.

Foner, N. (2001) Islands in the City: West Indian Migration to New York (Berkeley, CA: University of California Press).

Frucht, R. (1967) A Caribbean social type: neither peasant nor proletarian, Social and Economic Studies, 16(2), pp. 295-300.

Harden, S. (1985) Small is Dangerous: Microstates in a Macro World (London: Frances Pinter).

Katzenstein, P. J. (1985) Small States in World Markets: Industrial Policy in Europe (Ithaca, NY: Cornell University Press).

Katzenstein, P. J. (2003) "Small states" and small states revisited, New Political Economy, 8(1), pp. 9-30.

King, R. and Strachan, A. (1980) The effects of return migration on a Gozitan village, Human Organisation, 39(2), pp. 175-179.

Lee Kwan Yew (2000) From Third World to First: The Singapore Story 1965-2000 (New York: Harper Collins).

Lewis, J. P. (1991) Some consequences of giantism: the case of India, World Politics, 43(3), pp. 367-389.

Liou, F. M. and Ding, C. G. (2002) Subgrouping small states based on socio-economic characteristics, World Development, 30(6), pp. 1289-1306.

Looney, R. E. (1989) Macroeconomic consequences of the size of third world nations: with special reference to the Caribbean, World Development, 17(1), pp. 69-83.

Lowenthal, D. (1987) Social features, in C. G. Clarke and T. Payne (Eds), Politics, Security and Development in Small States (London: Allen and Unwin), pp. 26-49.

Marcus, G. E. (1981) Power on the extreme periphery: the perspective of Tongan elites in the modern world system, Pacific Viewpoint, 22(1), pp. 48-64.

Marx, K. ([1852] 2006) The Eighteenth Brumaire of Louis Bonaparte (London: Objective Systems).

Matsen, E. and Torvik, R. (2005) Optimal Dutch disease, Journal of Development Economics, 78(2), pp. 494-515.

McElroy, J. L. (2006) Small island tourist economies across the life cycle, Asia Pacific Viewpoint, 47(1), pp. 61-77.

Midttun, A., Gautesen, K. and Gjølberg, M. (2006) The political economy of corporate social responsibility in Western Europe, Corporate Governance, 6(4), pp. 369-385.

Oberst, A. and McElroy, J. L. (2007) Contrasting socio-economic and demographic profiles of two, small island, economic species: MIRAB versus PROFIT/SITE, Island Studies Journal, 2(2), pp. 163-176. 


\section{G. Baldacchino and G. Bertram}

Pahl, R. E. (1984) Divisions of Labour (Oxford: Blackwell).

Plischke, E. (1977) Microstates in World Affairs: Policy Problems and Options (Washington, DC: American Enterprise Institute for Policy Research).

Poirine, B. (1999) A theory of aid as trade with special reference to small islands, Economic Development and Cultural Change, 47(4), pp. 831-852.

Poon, A. (1990) Flexible specialisation and small size: the case of Caribbean tourism, World Development, 18(1), pp. 109-123.

Prasad, N. (2004) Escaping regulation, escaping convention: development strategies in small economies, World Economics, 5(1), pp. 41-65.

Price, N. (1988) Behind the Planter's Back: Lower Class Responses to Marginality in Bequia Island, St Vincent (London: Macmillan).

Punnett, B. J. and Morisson, A. (2006) Niche markets and small Caribbean producers: a match made in heaven? Journal of Small Business and Entrepreneurship, 19(3), pp. 341-354.

Qureshi, M. and te Velde, D. W. (2008) Working Smart and Small: The Role of Knowledge-based and Service Industries in Growth Strategies for Small States (London: Commonwealth Secretariat).

Richardson, B. C. (1983) Caribbean Migrants: Environment and Human Survival on St Kitts and Nevis (Knoxville, TN: University of Tennessee Press).

Schahczenski, J. J. (1992) Development administration in the small developing state, in R. Baker (Ed.), Public Administration in Small and Island States (West Hertford, CT: Kumarian Press), pp. 34- 48 .

Schmitz, H. (1989) Flexible specialisation: a new paradigm of small-scale industrialisation. Discussion Paper No. 261, Institute of Development Studies, Brighton, UK.

Sparke, M., Sidaway, J. D., Bunnell, T. and Grundy-Warr, C. (2004) Triangulating the borderless world: geographies of power in the Indonesia-Malaysia-Singapore growth triangle, Transactions of the Institute of British Geographers, 29(4), pp. 485-498.

Spickard, P., Rondillo, J. L. and Hippolite Wright, D. (2002) Pacific Diaspora: Island Peoples in the United States and Across the Pacific (Honolulu: University of Hawai'i Press).

Streeten, P. P. (1993) The special problems of small countries, World Development, 21(2), pp. 197-202.

Subramanian, A. and Roy, D. (2001) Who Can Explain the Mauritian Miracle: Meade, Romer, Sachs or Rodrik? IMF Working Paper WP/01/116, August.

Sultana, R. G. (2006) Challenges for Career Guidance in Small States (Msida, Malta: Euro-Mediterranean Centre for Educational Research).

Thorallsson, B. (2006) The size of states in the European Union: theoretical and conceptual perspectives, European Integration, 28(1), pp. 7-31.

Trouillot, M.-R. (1988) Peasants and Capital: Dominica in the World Economy (London: Johns Hopkins University Press).

Ueda, K. (2002) Implications of Migration on Income and Welfare of Nationals. IMF Working Paper WP/ $02 / 215$.

United Nations Committee on Development Policy (2005) Criteria for the identification of the least developed countries. Report on the Seventh Session (14-18 March 2005), Economic and Social Council Official Records, Supplement No. 33 (E/2005/33), pp. 16-18.

Walsh, B. (2004) Ireland's economic renaissance: the success of a 'peripheral' economy, in J. Poot (Ed.), On the Edge of the Global Economy (Cheltenham: Edward Elgar), pp. 265-286.

Wardle, H. (2002) Marshy and friends: informality, deformalization and West Indian Island Experience, Social Identities, 8(2), pp. 255-270.

Warrington, E. (1998) Gulliver and Lilliput in a new world order: the impact of external relations on the domestic policies and institutions of micro-states, Public Administration and Development, 18(1), pp. 101-105.

Warrington, E. and Milne, D. (2007) Island governance, in G. Baldacchino (Ed.), A World of Islands: An Island Studies Reader (Charlottetown, Canada and Luqa, Malta: Institute of Island Studies and Agenda Academic), pp. 379-428.

Weiner, J. (1994) The Beak of the Finch: A Story of Evolution in Our Time (New York: Vintage Books). Yeung Lam Ko, L. (1998) The economic development of Mauritius since Independence. Research Working Paper No. 6, School of Economics, University of New South Wales, Australia, wwwdocs.fce.unsw.edu.au/economics/Research/WorkingPapers/1998_6.pdf 